\title{
DOUBLE PYLORUS: CASE REPORT AND REVIEW OF THE LITERATURE
}

\author{
Adriana Vaz Safatle-Ribeiro, Ulysses Ribeiro Júnior, Angelita Habr- \\ Gama and Joaquim J. Gama-Rodrigues
}

RHCFAP/2977

SAfATLE-RIBEIRO, A . V. et al. - Double pylorus: Case report and review of the literature. Rev. Hosp. Clín. Fac. Med. S. Paulo 54 (4): 131 - $134,1999$.

SUMMARY: Double pylorus is an unusual condition in which a double communication between the gastric antrum and the duodenal bulb occurs. It may be congenital, or it may be acquired complication of peptic ulcer disease. We present a case of double pylorus in a gentleman with epigastric pain and previous history of peptic ulcer disease. The relationship between Helicobacter pylori and this disease was assessed. A review of the literature, the role of associated diseases and the role of $\mathrm{H}$. pylori are discussed.

DESCRIPTORS: Double pylorus. Gastroduodenal fistula. Upper digestive endoscopy. Helicobacter pylori.

Double pylorus is a rare condition consisting of a gastroduodenal fistula extending from the gastric antrum to the duodenal bulb through an accessory canal. In the majority, it is due to a complication of peptic ulcer disease; however, it can also be congenital. It usually presents on the lesser curvature of the gastric antrum and on a superior wall of the duodenal bulb. It is commonly an endoscopic finding, since the clinical presentation is similar to other peptic diseases ${ }^{1,3,5-7,9}$.

In most patients, double pylorus responds well to medical treatment such as H2-antagonist, antacid, or proton pump inhibitors, regardless of whether or not the fistula remains patent $t^{6,9,16}$.

In this article, we describe one case of acquired double pylorus, the common associated diseases, and the possible relationship with infection by H. pylori.

\section{CASE REPORT}

A 61-year-old male with a history of a previous gastric ulcer treated with $\mathrm{H} 2$-antagonist and antacid presented with epigastric pain. He had undergone surgical treatment and radiotherapy for laryngeal tumor seven years ago. He also had been treated for high blood systemic pressure. His physical examination revealed no alterations.

The endoscope Olympus GIF130 was used to perform an upper gastrointestinal endoscopy. (Fig 1) It was introduced easily through the left piriform sinus. A small deformity with scarring retraction on the

From "Clínica Cirúrgica do Aparelho Digestivo da Faculdade de Medicina da Universidade de São Paulo". right piriform sinus and arytenoid was observed, however, no lesion suggesting tumoral recurrence was found. The exam revealed a mild erythematous gastritis of the antrum. The presence of two channels with access to the duodenal bulb and separated by a tissue bridge were also noted. The pyloric ring was deformed and had a scar in the anterior wall and lesser curvature. The channel near the greater curvature had a smaller diameter, minor deformity, and presented contractions, suggesting that it could be the true pyloric ring. Urease tests and a histopathological exam were positive for H. pylori. Biopsies from the cicatricial area were taken, and the pathological exam revealed chronic inflammation. The patient was treated with antibiotics (amoxicillin and metronidazole) for $\mathrm{H}$. pylori and proton pump inhibitors and has been asymptomatic for one year. 


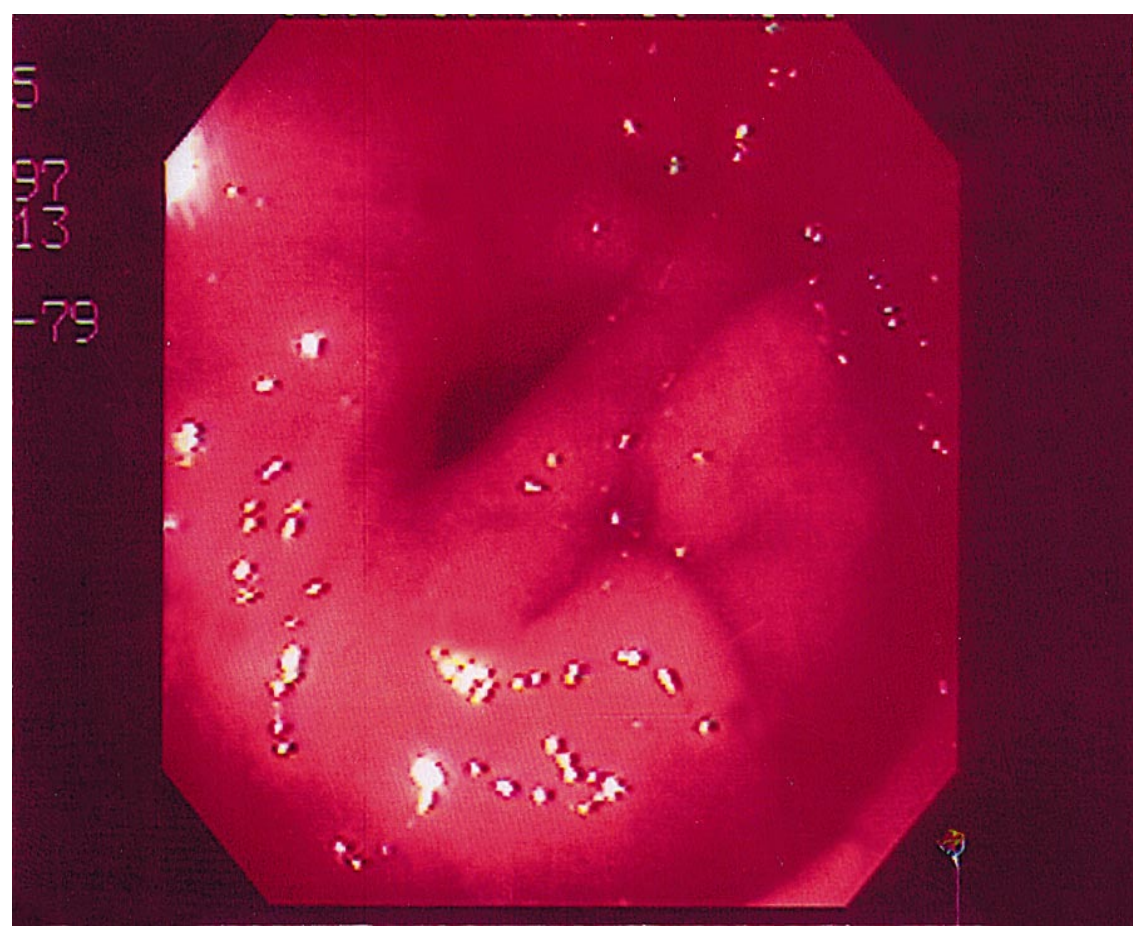

Figure 1: Endoscopic view of a double pylorus. The bridge between the two channels is easily visualized.

\section{DISCUSSION}

The prevalence of double pylorus varies from 0.06 to $0.4 \%$; however, its real incidence remains unknown $n^{5,9}$. It occurs more often in men $(2: 1)$, as well as with other peptic diseases ${ }^{5,9}$. It can also be called: peripyloric gastroduodenal fistula, double channel pylorus, pyloric duodenal fistula, and antral duodenal fistula ${ }^{1,3,5-7,9,14,16 .}$

Double pylorus can be congenital or acquired. The first case of congenital double pylorus was published by Christien et al., in 19712. Only few more cases have been reported since then ${ }^{15}$. In congenital double pylorus, an error of canalization seems to occur. The diagnosis is based on the normal histology of both channels, in the absence of an ulcer, and also by the endoscopic findings. The bridge between the two channels has normal muscle layer, differing from acquired double pylorus ${ }^{10 .}$
The majority of reported cases of double pylorus are acquired and are attributed to complications of ulcers at the antrum-pyloric area or at the duodenal bulb. Most of them are consequences of gastric ulcer, and only few cases are due to duodenal ulcer ${ }^{1,5-}$ $7,9,14,16$. In this patient, the previous history of gastric ulcer and the presence of scar tissue at the endoscopic examination indicated that the lesion was acquired.

The pathological explanation for this fistula is that the peptic ulcer at the gastric antrum or at the duodenal bulb causes adhesion between the adjacent walls of stomach and duodenum with posterior penetration along the muscular layer, leading to a fistulous tract that becomes epithelized ${ }^{1,5,6,9}$.

Diagnosis of double pylorus is important because of the possibility of recurrent ulcers that can occur, probably due to a failure of formation of epithelium in the fistulous $\operatorname{tract}^{1,6,14}$. The reasons for development of double pylorus are not known, but many systemic diseases contributing to poor healing may be associated, such as diabetes mellitus ${ }^{2,10,14-16}$. In diabetes the lack of microcirculation can be the cause ${ }^{16}$. Other affections such as chronic obstructive pulmonary disease, chronic renal failure, chronic rheumatism, and systemic lupus erythematosus can also be related to poor healing $8,11,13,16$. Additionally, drugs used for long periods by the patients, including steroid or non-steroid anti-inflammatory analgesics, may play a role in the formation of the fistula. In the present case, the fact that the patient underwent radiotherapy, and the stress caused by the treatment of his laryngeal tumor may be related to this fistula.

The clinical symptoms of acquired double pylorus are similar to those caused by the peptic ulcer disease and can occur before, at the time of, or even after the fistula formation. A few patients report relief of the symptoms after the fistula formation, which is attributed to the improvement of gastric emptying through the fistula, which acts as a gastroduodenostomy. On the other hand, when these symptoms persist even after the formation of the fistula, it may be implied that the accessory pylorus does not have adequate function, resulting in duodenal reflux and maintenance of the ulcer $^{4,6,12-14}$

The majority of the patients respond well to medical treatment, regardless of whether the fistula is open or closed. However, refractory symptoms can occur in about $20 \%$ of the patients, and surgical treatment is necessary $6,9,13,14,16$. With the use of potent inhibitors of acid production such as the proton pump inhibitors, we believe that this number may be reduced.

In this patient, the urease test and the histological examination for $\mathrm{H}$. pylori were positive. It is known that 
H. pylori plays a role in the pathogenesis of the duodenal ulcer disease and in the majority of peptic gastric diseases. Based on literature, H. pylori may be responsible for refractory cases and the lack of healing. So, shar- ing the opinion of other authors ${ }^{6}$, we believe that the antibacterial therapy must be considered in order to decrease the risk of new ulcer formation, and also to improve the healing of the fistula.
In conclusion, acquired double pylorus is a rare complication of peptic ulcer disease that can be associated with other diseases and $\mathrm{H}$. pylori colonization. Therefore, the adequate treatment consists of the correction of these factors.
SAFATLE-RIBEIRO, A .V . et al. Duplo Piloro: Estudo de caso e revisão da literatura Rev. Hosp. Clín. Fac. Med. S. Paulo 54 (4): 131 - 134, 1999.

Duplo piloro é condição rara em que se forma dupla comunicação entre o antro gástrico e o bulbo duodenal. Pode ser congênito ou adquirido como complicação de doença cloridropéptica. Apresentamos caso de duplo piloro adquirido em paciente masculino com epigastralgia e história prévia de úlcera péptica. A pesquisa do Helicobacter pylori foi positiva em amostras de tecido gástrico. Foi realizada revisão da literatura e discutido o papel de doenças associadas e do Helicobacter pylori na etiopatogenia desta afecção.

DESCRITORES: Duplo piloro. Fístula gastroduodenal. Endoscopia digestiva alta. Helicobacter pylori.

\section{REFERENCES}

1. CAPPElletti F, RECCHIA S, BONARDI L et al. Gastroduodenal fistula complicating a prepyloric ulcer. Gastrointest Endosc 1983; 29:111-113.

2. CHRISTIEN G, BRANTHOMME J M, VOLNY L et al. Pylore double: Malformation congenitale. Sem Hop 1971; 47:1485-1488

3. ENGLE R B - Tunnel ulcer with double pyloric canal. Diagn Radiol 1975; 16:323-4.

4. FAYENZ S - The evolution of the double pylorus. Gastrointest Endosc 1986; 32:31-32.

5. HEGEDUS V, POULSEN PE \& REICHARDT J - The natural history of the double pylorus. Radiology 1978; 126:29-34.

6. HU T H, TAI D I, CHANGCHIEN C S et al. - Double pylorus: report of a longitudinal follow-up in two refractory cases with underlying diseases. Am J Gastroenterol 1995; 90:815-818.

7. JAMSHIDNEJAD J, KOEHLER R \& NARAYAN D - Double channel pylorus. Roentgenology 1978; 130:1047-1050.
8. Kelly M E, MOHTAShemi H, PATEL S H et al. - Report of a case of double pylorus. Dig Dis Sci 1979; 24:807-810.

9. KOTHANDARAMAN K R, KUTTY K P, HAWKEN A $\mathrm{S}$ et al. - Double pylorus in evolution. J Clin Gastroenterol 1983; 5:335-338.

10. MINOLI G, TERRUZZI V, LEVI C et al. - Acquired double pylorus or gastroduodenal fistula: Report of a case and review of the literature. Digestion 1981; 21:1-5.

11. MUNEHISA T, HARADA R \& TEZUKA H - Double pylorus complicated with systemic lupus erythematosus: Report of a case Gastroenterol Endosc 1982; 12:1960-1965.

12. POLLONI A, MARCHI S, BELLINI M et al. - Double pylorus: report of two cases and review of the literature. Ital J Gastroenterol 1991; 23:360-363.

13. ROMERO JR V, CARRACEDO G E \& VALLEJO G L - Double pyloric canal. Presentation of 3 new cases and review of the literature. Rev Esp Enferm Apar Dig 1989; 75:185-187. 
14. SANTOS J O M, VARANDA E, MONTES C G et al. - Dados clínicos e endoscópicos de sete casos de duplo canal pilórico e revisão da literatura. GED 1995; 14:254-256.

15. SUFIAN S, OMINSKY S \& MATSUMOTO $\mathrm{T}$ - Congenital double pylorus: A case report and review of the literature. Gastroenterology 1977; 73:154-157.
16. YOSHIMURA Y, YASUTAKE K, IMAMURA Y et al. - Double pylorus accompanied by gastric ulcer resistant to H2-receptor antagonist: A case report and review of the literature. Kobe $\mathbf{J}$ Med Sci 1988; 34:151-159.

Received for publication on the $05 / 05 / 99$ 